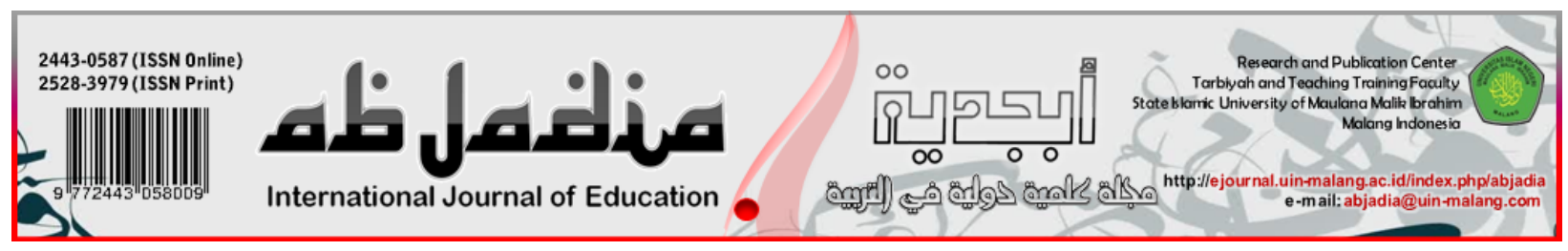

\title{
INVESTIGATING POSITIVE PERCEPTIONS OF HIGH SCHOOL STUDENTS' DISTANCE LEARNING EXPERIENCES DURING A PANDEMIC
}

\author{
Agus Purnomo Ahmad Putikadyanto', Gamal Kusuma Zamahsari², Wiga Alif Violando ${ }^{3}$ \\ ${ }^{1}$ IAIN Madura, Indonesia \\ 2Universitas Bina Nusantara, Jakarta, Indonesia \\ ${ }^{3}$ UIN Sunan Ampel Surabaya, Indonesia
}

\begin{abstract}
Article History:
Received : 2021-11-05

Revised : 2021-11-24

Accepted : 2021-12-24

Published : 2021-12-26
\end{abstract}

\section{Keywords:}

Covid 19 Pandemic, Distance Learning, High School Student, Students'

Perceptions

*Correspondence Address:

aguspurnomo@iainmadura.ac.id

\begin{abstract}
Covid-19 has driven pedagogical transformation in the most unexpected and sudden way in education history. Students must switch from face-to-face to distance learning. Trough quantitative research model, this study aims to describe high school students' perceptions of distance learning. Samples were collected from school which might prepare their students for distance learning. Using a questionnaire data collection technique, a sample of 70 high school students received 40 questions derived from three perceptual indicators, namely absorption, understanding, and assessment. The results of this study's absorption, understanding, and assessment indicator scores which were higher than the median indicated that students' perceptions of distance learning were typically positive. This occurs as a result of collaboration between students, teachers, and school staff to accomplish effective distance learning.
\end{abstract}

\section{C) Introduction}

The Covid-19 pandemic has had a significant social impact. This pandemic's ramifications and domino effects are impossible to foresee and control (Boivin \& Welby, 2021; Voigt \& Smith, 2021). In Indonesia, the education sector has had a considerable impact (Wulandari, 2020). Due of the Covid-19 pandemic, nearly all levels of education in Indonesia were physically shuttered in the middle of the first semester of 2020. Furthermore, distance learning is carried out (in addition to mixed learning) as an alternative chosen so that learning activities continue to run. Teachers are making rapid changes to their learning in the remainder of the even semester 2020.

The transition from face-to-face to distance learning occurs abruptly and unexpectedly (Rodríguez-Muñiz, Burón, \& Aguilar-González, 2021). COVID-19 has prompted the most significant and rapid shift in pedagogy in modern education(Baker, 2021). Many educators aren't up to the task. Students, instructors, and education professionals experience disruption, uncertainty, and irritation as a result of these abrupt shifts (Cahill, Kripchak, \& McAlpine, 2021; Scott, 2020). Although face-to-face learning is preferred, educators are compelled to continue their work online. This is problematic since online learning is not pre-planned. Many students, particularly those in remote 
areas, lack access to reliable and adequate internet service. Lack of access to technology, along with uncertain situations, such as educational programs, one's own and family members' health and safety, contributes significantly to worry and stress (Bao, 2020; Cao et al., 2020).

Several research have revealed that online learning isn't necessarily easier or more difficult than traditional learning (Appavoo, Sukon, Gokhool, \& Gooria, 2019; He \& Wei, 2021; Leichty, 2021; Ranjan, 2020). For some teachers and students, the abrupt pedagogical shift from face-to-face instruction to online distance learning may be unsettling. Others may be more at ease and open to online learning. However, some students may struggle with some lessons when learning online. For example, practical laboratory study necessitates physical presence at school. Although quality learning can be achieved through online learning, the abrupt transition from face-to-face to online learning has the potential to lower overall teaching quality(Flynn-Wilson \& Reynolds, 2021; Herold, 2021).

Support for the availability of technical devices as well as technological proficiency might be critical to the success of online education (Zamahsari, Putikadyanto, \& Maulana, 2020). Furthermore, online learning has its own set of challenges, such as (a) a sense of isolation due to a lack of peer interaction ( $\mathrm{Vu} \&$ Fadde, 2013), (b) difficulties with handson learning activities(Mawn, Carrico, Charuk, Stote, \& Lawrence, 2011); (c) limited teacher attendance( $\mathrm{Vu}$, Fredrickson, \& Meyer, 2016). As a result, regardless of whether stakeholders are prepared or not, the abrupt and unprecedented transfer from traditional learning to remote learning (online emergency learning) could be a big shock for teachers and students.

Teachers and students are expected to fulfill their tasks in a unique way during this pandemic. Teachers and students must both continue to teach and learn. Online learning, sometimes known as e-learning, is a viable option. E-learning is a new type of distance education that allows teachers to use cutting-edge technology to create more engaging classrooms even when teachers and students are separated by distance (Magdin, 2016; Salehudin, Zulherman, Arifin, \& Napitupulu, 2021). As a result, it is believed that learning will be able to continue.

Students confront a number of issues as they transition from face-to-face learning to online distant learning. Scheidel discovered through his research that when face-toface learning transforms into online learning, students with financial issues try to keep up, but many fall behind (Dietz, 2021). This demonstrates that the epidemic has exposed the frailty of several societal sectors (Gross, 2020; Munday, 2021). Many children from moderate to lower socioeconomic backgrounds may not have access to computers or other forms of communication that can be used for learning (smartphones). Many students in the middle and lower economic classes lack access to educational resources such as libraries and the internet, which are critical for remote education during this pandemic. During this pandemic, the health and economic crises appears to have had a 
substantial impact on schooling, particularly among students (Rotas \& Cahapay, 2020; Samat, Awang, Hussin, \& Nawi, 2020).

Students have different opinions about online learning and their new reality. This perception is important to understand to improve the online learning environment(Guberman, 2021; Li \& Zhang, 2021). With this research on student perceptions, we can see what students think about the pros and cons of new forms of learning due to the COVID-19 pandemic and how teachers are trying to adapt. Perception can help understand a person's motivation and how they will react to different situations(Al Ghazali, 2020; Vawter, 2019). In terms of these new classrooms and environments, it is important to understand what students are thinking to help teachers plan for the future. Students' perception of this new reality can provide new insights into how the COVID-19 pandemic has changed the face of education and how it moves forward.

Several indicators can be used to determine a person's perception, which can be classified as positive or negative emotions. Walgito identified three perception indicators: absorption, understanding, and assessment (Walgito, 2010). Absorption indicates that the brain receives images, responses, and impressions from the stimuli acquired by the senses as a result of absorption. To build understanding, the pictures, responses, and impressions are also classified, compared, structured, and interpreted. Then there will be an individual assessment. The individual subjectively compares the new understanding or understanding to the standards or norms that he or she has.

At the very least, these three signs can reveal a person's perception. These indicators will serve as the foundation for developing the instruments that will be utilized to gather data for this study. As a result, a description of students' perceptions of onlinebased Indonesian learning will be obtained, which can be classified as good or negative.

Research on students' perceptions of learning, especially Indonesian language learning, is important and needs to be done. This study can be used as a recommendation for education in Indonesia. The hope is that it can improve the quality of education during the pandemic.

Based on the background described previously, this study aims to describe students' perceptions of distance learning. The specific objectives of this study were to describe students' perceptions of the absorption of distance learning, to describe students' perceptions of the understanding of distance learning, and to describe students' perceptions of the assessment of distance learning. Senior High School 1 Pasuruan is one of the favorite public schools in Pasuruan and is considered representative of this research. 


\section{[Q] Method}

In this study, a quantitative approach with descriptive type was adopted. During the pandemic, this method was utilized to determine students' impressions of onlinebased Indonesian language study. Student impressions were gathered through questionnaires that were presented to pupils and then turned into scores. This study took place at Senior High School 1 Pasuruan in August 2021. The participants in this study were Senior High School 1 Pasuruan students. Because they are one of the leading schools in Pasuruan and have introduced e-learning before the epidemic, these schools were chosen as the population. This study used a random sample strategy to collect data. A sample of 70 class X and XI students from Senior High School 1 Pasuruan was obtained using this technique.

The data collection technique in this study used a questionnaire based on the consideration of the effectiveness of data collection. Questionnaires are a number of written questions that are used to obtain information from respondents about things that respondents know (Arikunto, 2018). The questionnaire or questionnaire used as a research instrument was a list of 40 statements with a checklist of answer choices using a Likert scale Strongly Agree (SS), Agree (S), Disagree (TS), and Strongly Disagree (STS). The questionnaire was given online using a google form.

\begin{tabular}{|l|l|l|}
\hline \multirow{3}{*}{ Indicator } & Sub-Indicator & $\begin{array}{l}\text { Number of } \\
\text { Questions }\end{array}$ \\
\hline \multirow{4}{*}{ Absorption } & Overview of online-based Indonesian learning & 5 \\
\cline { 2 - 3 } & Response to online-based Indonesian learning & 5 \\
\cline { 2 - 3 } & Impressions of online-based Indonesian language learning & 5 \\
\hline \multirow{2}{*}{ Understanding } & Compile Indonesian online-based assignments in groups & 5 \\
\cline { 2 - 3 } & Arrange individual online-based Indonesian assignments & 5 \\
\hline \multirow{3}{*}{ Assessment } & Implementation of online-based Indonesian learning towards attitudes & 5 \\
\cline { 2 - 3 } & Implementation of online-based Indonesian learning on knowledge & 5 \\
\cline { 2 - 3 } & Implementation of online-based Indonesian learning on skills & 5 \\
\hline \multicolumn{2}{|l|}{ Number of Questions on the Questionnaire } & 40 \\
\hline
\end{tabular}

Table 1. Grid for Making Questions on the Questionnaire

In accordance with Walgito's theory that perception indicators can be seen from 3 factors, namely absorption, understanding, and assessment, the making of questions in this research questionnaire is guided by this, as shown in the table above. There are subindicators of absorption indicators in the form of an overview of online-based Indonesian learning, responses to online-based Indonesian learning, and impressions of online-based Indonesian learning. There are sub-indicators of understanding indicators in the form of Compiling Indonesian online-based assignments in Groups and Composing individual online-based Indonesian tasks. The assessment indicators have sub-indicators in the form of Implementation of online-based Indonesian learning on Attitude, Implementation of online-based Indonesian learning on Knowledge, Implementation of online-based Indonesian learning on Skills. Each sub-indicator is reduced to 5 questions so that the total number of questions in this research questionnaire is 40 . After the data is collected, then the data analysis is carried out. Quantitative data analysis begins with scoring each 
statement item. The questions on the questionnaire are negative so that SS is given a score of $1, \mathrm{~S}$ scores 2, TS scores 3, and STS 4 . The scores are added up for each sub-indicator, indicator, and then as a whole. Perception indicators of this research are absorption, understanding, and assessment. Furthermore, it is classified into 2 classifications, namely high (positive) and low (negative).

\section{Result}

Perception of Absorption Indicators in High School Students' Distance Learning Experiences During the Pandemic

The table below shows the results of high school students' perceptions of absorption indicator in their distance learning experience during the pandemic.

Table 2. Data on the results of high school students' perceptions of absorption indicators in their distance learning experiences during the pandemic

\begin{tabular}{|l|l|l|l|}
\hline Indicator & Sub-Indicator & Score & Category \\
\hline \multirow{3}{*}{ Absorption } & Overview of distance learning & 799 & positive \\
\cline { 2 - 4 } & Response of distance learning & 907 & positive \\
\cline { 2 - 4 } & Impression of distance learning & 886 & positive \\
\hline $\begin{array}{r}\text { Information: }>700=\text { positive } \\
<700=\end{array}$ & Megative & Max score =1400 \\
\hline
\end{tabular}

Absorption is one indicator of perception. These variables were broken down into three sub-indicators in this study: distance learning overview, responses to distance learning, and impressions of distance learning. The distance learning description subindicator got a score of 799 out of a maximum of 1400 based on the findings of the study in the table above. This indicates that the score is higher than the median, indicating that it belongs to the favorable perception group. The distant learning response is the following sub-indicator, with a score of 907 out of a possible 1400. That is, the score is higher than the median, indicating that it belongs to the positive category. The following sub-indicator, the perception of distance learning, receives an 886 out of a possible 1400 score. That is, because the score is higher than the median, it can be classified as positive perception. The absorption indicator receives a total score of 2592 out of a maximum 4200 . This indicates that the score is higher than the median, indicating that it belongs to the positive perception category.

Perception of Understanding Indicators in High School Students' Distance Learning Experiences During the Pandemic

The table below shows the results of high school students' perceptions of understanding indicator in their distance learning experience during the pandemic. 
Agus Purnomo Ahmad Putikadyanto, Gamal Kusuma || Investigating Positive Perceptions of High School Students' Zamahsari, Wiga Alif Violando || Distance Learning Experiences During a Pandemic

Table 3. Data on the results of high school students' perceptions of understanding indicators in their distance learning experiences during the pandemic

\begin{tabular}{|l|l|l|l|}
\hline Indicator & Sub-Indicator & Score & Category \\
\hline \multirow{2}{*}{$\begin{array}{l}\text { Understanding } \\
\text { Information: }>700=\text { positive } \\
<700=\text { negative }\end{array}$} & 876 & positive \\
\cline { 2 - 4 } & Arrange group task & 974 & positive \\
\hline
\end{tabular}

Understanding is one indicator of perception. These indicators are reduced to two sub-indicators in distance learning, namely group tasks and individual tasks. The subcomposing the group based online Indonesian assignment got an 876 out of a maximum score of 1400 , according to the results of the analysis in the table above. This means that the score is larger than median, indicating that it belongs to the positive perception category. Compiling an individual online-based Indonesian task with a score of 924 out of a maximum of 1400 is the following sub-indicator. This means that the score is higher than the median, indicating that it belongs to the positive perception category. The understanding indicator receives an overall score of 1800 out of a possible 2800 . This means that the score is larger than median score, indicating that it belongs to the positive perception category.

Perception of Assessment Indicators in High School Students' Distance Learning Experiences During the Pandemic

The table below shows the results of high school students' perceptions of assessment indicator in their distance learning experience during the pandemic.

Table 4. Data on the results of high school students' perceptions of assessment indicators in their distance learning experiences during the pandemic

\begin{tabular}{|l|l|l|l|}
\hline Indicator & Sub-Indicator & Score & Category \\
\hline \multirow{3}{*}{ Assessment } & Implementation of distance learning on attitude & 1021 & positive \\
\cline { 2 - 4 } & Implementation of distance learning on knowledge & 868 & positive \\
\cline { 2 - 4 } & Implementation of distance learning on skill & 898 & positive \\
\hline $\begin{array}{l}\text { Information: }>700=\text { positive } \\
<700=\text { negative }\end{array}$ & Max score $=1400$ \\
\hline
\end{tabular}

Assessment is one indicator of perception. These indicators are broken down into three sub-indicators in distance learning: distance learning implementation on attitudes, distance learning implementation on knowledge, and distance learning implementation on skills. The sub-indicator of distance learning implementation on attitudes got a score of 1021 out of a maximum score of 1400 based on the results of the analysis in the table above. That is, because the score is higher than the median, it can be classified as positive perception. The next sub-indicator is the implementation of distance learning on knowledge, which gets an 868 out of a maximum 1400 score. That is, because the score is higher than the median, it can be classified as favorable perception. The application of distant learning on skills that receive a score of 898 out of a maximum of 1400 is the 
following sub-indicator. That is, the score is greater than the median so it can be said to be in the category of positive perception. Overall, the assessment indicator got a score of 2787 out of a maximum score of 4200 . This means that the score is greater than the median so that it can be said to be in the category of positive perception.

\section{iinj Discussion}

Perception of Absorption Indicators in High School Students' Distance Learning Experiences During the Pandemic

In this study, absorption indicators are divided into 3 sub-indicators, namely distance learning overview, responses to distance learning, and impressions of distance learning. The total rating for overview distance learning is 799, putting it in the positive category. Students at Senior High School 1 Pasuruan had a generally good perception toward distant learning during the Covid-19 pandemic. Students have a good understanding of distance learning. This could be attributed to a number of factors, including the fact that students at Senior High School 1 Pasuruan were already experienced with online learning (e-learning) and had no difficulty understanding the texts given in distance learning. For successful distance learning, it is important to have access to helpful resources (Arthur-Nyarko, 2019; Kazu \& Is, 2018; KewalRamani, 2018).

The response to distance learning got a score of 907, putting it in the positive category. Students at Senior High School 1 Pasuruan have a positive perception on the response to distance learning during the Covid-19 pandemic. Distance learning has already received a positive response from students. This could be due to a number of factors, including Senior High School 1 Pasuruan students being interested in their studies, students performing well in distance learning classes, and students remaining motivated during distance learning. Student participation can help students learn more effectively in the classroom (S. Can \& Deniz, 2019; Olson, 2021; Zamahsari, Putikadyanto, \& Ansori, 2021).

The impression of distance learning got an 886, putting it in the positive category. Students at Senior High School 1 Pasuruan have a generally positive impression of distance learning during the Covid-19 pandemic. Distance learning has a positive perception among students. This could be due to a variety of factors, including Senior High School 1 Pasuruan students receiving distance learning in a fun design that is not dull, and Senior High School 1 Pasuruan students obtaining distance learning swiftly. Students are more receptive to learning when it is presented in an attractive manner (An \& Mindrila, 2020; Sarigöz, 2019).

Perception of Understanding Indicators in High School Students' Distance Learning Experiences During the Pandemic

In this study, understanding indicators are divided into 2 sub-indicators, namely group tasks and individual tasks. Composing group task got an 876, which placed it in 
the positive category. During the Covid-19 pandemic, students at Senior High School 1 Pasuruan have a generally positive perception toward group assignment preparation. Students did not encounter any significant challenges while preparing group assignments for distance learning. This could be due to a variety of factors, including Senior High School 1 Pasuruan students' ability to work well together in the classroom even during a pandemic. Collaboration among students can help them study more effectively (A. Can, Poyrazl, \& Pillay, 2021; F. Can, 2020).

Compiling a individual online-based task got a 924, putting it in the positive category. During the Covid-19 pandemic, students at Senior High School 1 Pasuruan have a positive perception in completing individual tasks. In the preparation of individual distance learning assignments, students did not encounter any significant difficulties. This could be due to a variety of factors, including Senior High School 1 Pasuruan pupils' ability to perform activities in learning on their own throughout the pandemic. Students' independence in completing class assignments can help them study more effectively (Jitanan, Somanandana, Jitanan, Lalitpasan, \& Kham-in, 2021; Kang, 2020).

Perception of Assessment Indicators in High School Students' Distance Learning Experiences During the Pandemic

In this study, assessment indicators are divided into 3 sub-indicators, namely distance learning implementation on attitudes, distance learning implementation on knowledge, and distance learning implementation on skills. The impact of distance learning on attitudes got a score of 1021, placing it in the positive category. Students at Senior High School 1 Pasuruan had a positive attitude about the use of distance learning in regards to attitudes during the Covid-19 pandemic. Students at Senior High School 1 Pasuruan believe that the lessons they are given inspire them to be more spiritual. Students are inspired by texts in the classroom to be honest, punctual in completing homework, and use polite language. As a result, the learning and text material in it can inspire the students of Senior High School 1 Pasuruan to have a spiritual attitude. Students' spiritual attitudes can be influenced by well-taught learning (F. Can, 2021; Kaymakci \& Can, 2021).

The positive category was assigned to the implementation of distance learning on knowledge, which got a score of 868. Students at Senior High School 1 Pasuruan had a positive attitude about the use of distance learning in regards to attitudes during the Covid-19 pandemic. Senior High School 1 Pasuruan students believe that the learning they are receiving contributes sufficiently to their knowledge. During the pandemic, students at Senior High School 1 Pasuruan believe that the text given in class contributes to their knowledge, despite the fact that it is delivered via online learning, which has limits. Students' knowledge must be enhanced through classroom learning (Fuchs, 2021; Knight, 2017).

With an 898 score, the implementation of distance learning on attitudes was 
classified as positive. Students at Senior High School 1 Pasuruan had a positive attitude about the use of distance learning in regards to attitudes during the Covid-19 pandemic. Senior High School 1 Pasuruan students believe that the learning they are receiving contributes adequately to their skills. Students of Senior High School 1 Pasuruan are still able to answer critical questions in classroom learning, retell the texts that are taught, and create texts that are taught in class while they learn online. Students' skills are enhanced by good classroom instruction (Evmenova, Regan, Ahn, \& Good, 2020; Sejdiu, 2017).

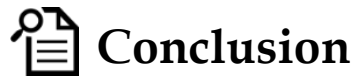

Students of Senior High School 1 Pasuruan have a positive perception of distance learning. The perception indicators are grouped into three categories: absorption, understanding, and distance learning assessment. According to the results of this study, students at Senior High School 1 Pasuruan have a positive perceptions toward online learning on all three indicators. These positive perceptions are based on factors, such as students already familiar with online learning, students are active and enthusiastic in learning, distance learning is fun packed, between students can be fun, students can independently complete the tasks given. The results of this study open up opportunities for further research on the factors causing these positive perceptions using an appropriate approach.

\section{Bibliography}

Al Ghazali, F. (2020). Learners' Perceptions on Using Social Networking Sites to

Reinforce Their Linguistic Performance. Journal of Language and Linguistic Studies, 16(2), 580-594. Retrieved from www.jlls.org

An, Y., \& Mindrila, D. (2020). Strategies and Tools Used for Learner-Centered

Instruction. International Journal of Technology in Education and Science, 4(2), 133-

143. Retrieved from www.ijtes.net

Appavoo, P., Sukon, K. S., Gokhool, A. C., \& Gooria, V. (2019). Why Does Collaborative

Learning Not Always Work Even When the Appropriate Tools Are Available?.

Turkish Online Journal of Distance Education, 20(4), 11-30.

Arthur-Nyarko, E. M. G. (2019). Learner Access to Resources for eLearning and Preference for Elearning Delivery Mode in Distance Education Programs in Ghana. International Journal of Educational Technology, 6(2), 1-8. Retrieved from http://educationaltechnology.net/ijet/

Baker, M. A. (2021). Educational Distancing: A Mixed-Methods Study of Student Perceptions in the Time of Coronavirus. JOURNAL OF HOSPITALITY \& TOURISM EDUCATION, 33(3), 207-221.

Bao, W. (2020). COVID-19 and online teaching in higher education: A case study of Peking University. Human Behavior and Emerging Technologies, 2(2), 113-115. 
Boivin, J. A., \& Welby, K. (2021). Teaching Future Educators during a Global Pandemic. IAFOR Journal of Education, 9(2), 25-36.

Cahill, J. L., Kripchak, K. J., \& McAlpine, G. L. (2021). Residence to Online:

Collaboration during the Pandemic. Journal of Teaching and Learning with Technology, 10, 80-87.

Can, A., Poyrazl, S., \& Pillay, Y. (2021). Eleven Types of Adjustment Problems and Psychological Well-Being among International Students. Eurasian Journal of Educational Research, 91(1), 1-20.

Can, F. (2020). Perceptions of Turkish Teachers about Listening Types. African Educational Research Journal, 8(3), 76-88.

Can, F. (2021). Examining the Relationship between Turkish Teacher Candidates' Metacognitive Learning Strategies and Critical Listening Attitudes. Shanlax International Journal of Education, 9(1), 145-153.

Can, S., \& Deniz, S. (2019). Motives of Pre-Service Classroom Teachers for Sports Activity Participation. Educational Policy Analysis and Strategic Research, 14(4), 151166. Retrieved from https:// doi.org/10.29329/epasr.2019.220.9

Cao, W., Fang, Z., Hou, G., Han, M., Xu, X., Dong, J., \& Zheng, J. (2020). The psychological impact of the COVID-19 epidemic on college students in China. Psychiatry Research, 11(2), 932.

Dietz, B. G. K. B. C. M. (2021). Pivoting during a Pandemic: Creating Presence for All Students. Journal of Teaching and Learning with Technology, 10, 194-206.

Evmenova, A. S., Regan, K., Ahn, S. Y., \& Good, K. (2020). Teacher Implementation of a Technology-Based Intervention for Writing. Learning Disabilities: A Contemporary Journal, 18(1), 27-39.

Flynn-Wilson, L., \& Reynolds, K. E. (2021). Student Responses to Virtual Synchronous, Hybrid, and Face-to-Face Teaching/Learning. International Journal of Technology in Education, 4(1), 46-56.

Fuchs, K. (2021). Bringing ICT into the Classroom: Perceptions from Tourism Students on Technology-Enhanced Learning. Education Quarterly Reviews, 4(2), 115-121.

Gross, B. A. (2020). Too Many Schools Leave Learning to Chance during the Pandemic. Center on Reinventing Public Education.

Guberman, D. (2021). Student Perceptions of an Online Ungraded Course. Teaching $\mathcal{E}$ Learning Inquiry, 9(1), 86-98.

He, W., \& Wei, G. (2021). Higher Education in China, a Paradigm Shift from Conventional to Online Teaching. Higher Education Studies, 11(2), 30-41.

Herold, D. S. | Chen. T. (2021). Switching from Face-to-Face to Online Instruction Midsemester: Implications for Student Learning. Journal of Teaching and Learning with Technology, 10, 321-336.

Jitanan, M., Somanandana, V., Jitanan, S., Lalitpasan, U., \& Kham-in, S. (2021). The 
Development of "Friend from Heart" Application Based on Line System to Promote Well-Being of Undergraduate Students of Faculty of Education, Kasetsart University. Higher Education Studies, 11(2), 215-223.

Kang, I. G. (2020). Heterogeneity of Learners' Behavioral Patterns of Watching Videos and Completing Assessments in Massive Open Online Courses (MOOCs): A Latent Class Analysis. International Review of Research in Open and Distributed Learning, 21(4), 221-237.

Kaymakci, G., \& Can, S. (2021). Investigation of the Effects of Some Variables on Middle School Students' Problem-Solving Skills, Science Process Skills and Learning Styles. Educational Policy Analysis and Strategic Research, 16(1), 394-426.

Kazu, I. Y., \& Is, A. (2018). An Investigation about Actualization Levels of Learning Outcomes in Early Childhood Curriculum. Journal of Education and Training Studies, 6(3), 66-77.

KewalRamani, A. J. X. A. L. M. J. (2018). Student Access to Digital Learning Resources outside of the Classroom. NCES 2017-098. National Center for Education Statistics.

Knight, T. (2017). Enhanced Student Success through Personalized Learning Strategies. BU Journal of Graduate Studies in Education, 9(1), 38-41.

Leichty, R. (2021). Online Learning for Rural Students. State Education Standard, 21(1), 12-17.

Li, L., \& Zhang, J. (2021). Successful Online Learning Experience: Perceptions of Chinese Undergraduate Students. Journal of Education and Learning, 10(1), 74-81.

Magdin, M. (2016). Even in E-Learning Is Important to Do Your Own Notes!. Turkish Online Journal of Educational Technology - TOJET, 15(3), 73-79.

Mawn, M. V., Carrico, P., Charuk, K., Stote, K. S., \& Lawrence, B. (2011). Hands- on and online: scientific explorations through distance learning. Open Learning: The Journal of Open, Distance and ELearning, 26(2), 135-146.

Munday, D. (2021). Teaching and Learning Post Pandemic. Research-Publishing.Net. https:/ / doi.org/10.14705/rpnet.2021.49.1219

Olson, L. (2021). How Can Learning Management Systems Be Used Effectively to Improve Student Engagement?. Center on Reinventing Public Education, (2).

Ranjan, P. (2020). Is Blended Learning Better than Online Learning for B.Ed Students?. Journal of Learning for Development, 7(3), 349-366. Retrieved from http:/ / www.qura.com/

Rodríguez-Muñiz, L. J., Burón, D., \& Aguilar-González. (2021). Secondary Mathematics Teachers' Perception of Their Readiness for Emergency Remote Teaching during the COVID-19 Pandemic: A Case Study. Education Sciences, 11.

Rotas, E. E., \& Cahapay, M. B. (2020). Difficulties in Remote Learning: Voices of Philippine University Students in the Wake of COVID-19 Crisis. Asian Journal of Distance Education, 15(2), 147-158. 
Salehudin, M., Zulherman, Arifin, A., \& Napitupulu, D. (2021). Extending Indonesia Government Policy for E-Learning and Social Media Usage. Pegem Journal of Education and Instruction, 11(2), 14-26.

Samat, M. F., Awang, N. A., Hussin, S. N. A., \& Nawi, F. A. M. (2020). Online Distance Learning amidst COVID-19 Pandemic among University Students: A Practicality of Partial Least Squares Structural Equation Modelling Approach. Asian Journal of University Education, 16(3), 220-233.

Sarigöz, O. (2019). The Effect of Educational Technologies on Manners and Sustainability of Teacher Candidates. African Educational Research Journal, 7(3), 143-152.

Scott, J. (2020). Redesign Resiliency during the COVID-19 Pandemic. Educational Considerations, 46(2).

Sejdiu, S. (2017). Are Listening Skills Best Enhanced through the Use of Multimedia Technology. Digital Education Review. Retrieved from http:/ /greav.ub.edu/der/ Vawter, D. (2019). Keynote. Motivation: Theory into Practice. Current Issues in Middle Level Education, 24(1).

Voigt, A., \& Smith, W. C. (2021). Inequalities in British University League Tables: The COVID-19 Pandemic and Halo Effects. International Journal of Multidisciplinary Perspectives in Higher Education, 6(1), 128-134.

Vu, P., \& Fadde, P. J. (2013). When to talk, when to chat: Student interactions in live virtual classroom. Journal of Interactive Online Learning, 12(2), 41-52.

Vu, P., Fredrickson, S., \& Meyer, R. (2016). Help at 3: 00 am! Providing 24/7 timely support to online students via a virtual assistant. Online Journal of Distance Learning Administration, 19(1).

Walgito, B. (2010). Pengantar Psikologi Umum. Yogyakarta: Andi Offset.

Wulandari, A. (2020). Dramatik Pembelajaran Daring Pada Masa Pandemi Covid-19. Mimbar PGSD, 8(3), 515-526. Retrieved from https:/ / ejournal.undiksha.ac.id/index.php/JJPGSD/article/view/29259

Zamahsari, G. K., Putikadyanto, A. P. A., \& Ansori, R. W. (2021). Ragam Pertanyaan Dan Teknik Bertanya Pengajar Bipa Dalam Interaksi Pembelajaran Di Kelas. Ghancaran: Jurnal Pendidikan Bahasa Dan Sastra Indonesia, 2(2), 125. https://doi.org/10.19105/ghancaran.v2i2.3912

Zamahsari, G. K., Putikadyanto, A. P. A., \& Maulana, F. I. (2020). The Contribution of Assessment Platform Technology to Promote Teacher's Work in Schools. 6th International Conference on Interactive Digital Media, ICIDM 2020. https://doi.org/10.1109/ICIDM51048.2020.9339634

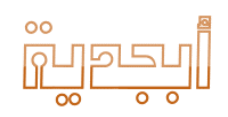

